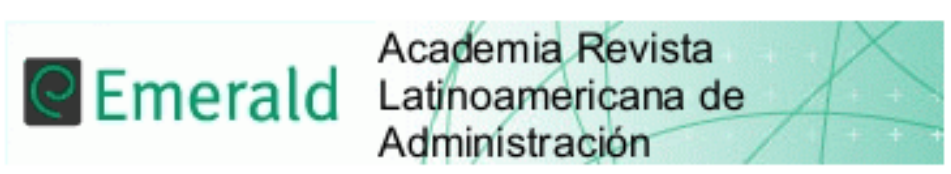

\title{
Determinants of foreign exchange risk management in Latin American firms
}

\begin{tabular}{|r|l|}
\hline Journal: & Academia Revista Latinoamericana de Administracion \\
\hline Manuscript ID & ARLA-03-2019-0072.R2 \\
\hline Manuscript Type: & Research Paper \\
\hline Keywords: & $\begin{array}{l}\text { Risk management, Foreign exchange risk, Hedging and derivatives, Logit } \\
\text { and Tobit models, Latin America, GIKA-LATAM-2019 }\end{array}$ \\
\hline
\end{tabular}

\section{SCHOLARONE \\ Manuscripts}




\title{
DETERMINANTS OF FOREIGN EXCHANGE RISK MANAGEMENT IN LATIN AMERICAN FIRMS
}

\begin{abstract}
Purpose: This study aims to identify whether Latin American (LA) firms are adopting any hedging strategy when designing Foreign Exchange Risk (FXR) measures. To that end, we explore the impact of several drivers of FXR management.
\end{abstract}

Design/methodology/approach: The sample consists of 342 non-financial listed firms established in a group of representative countries of the LA region and covers the period from 2008 to 2016. Hypothesis testing is performed through a Logit model that measures the likelihood to adopt hedging practices. In addition, a Tobit test offers further insights into the derivatives users.

Findings: We corroborate capital structure related hypotheses such as tax goals, financial distress, liquidity, and growth opportunities. In addition, both, ownership concentration and income tax payable seem to be negative and significant determinants of FXR coverage.

Originality/value: Results reported in this study are relevant for the LA region with high tradition in raw materials and commodities exports. Our results show that LA firms still make limited use of derivatives and there is still much room for improvement. Hence, additional efforts to promote FXR hedging should be desirable, to meet authorities' recommendations (OECD, World Bank, and IMF, 2007). Further research exploring Corporate Governance (CG) relationships and differences between large and small firms might be helpful.

Keywords: risk management, foreign exchange risk, hedging, derivatives, Logit, Tobit, Latin America, GIKA-LATAM-2019.

JEL: G32 


\section{DETRMINANTES DE LA GESTIÓN DEL RIESGO DE TIPO DE CAMBIO EN EMPRESAS DE AMÉRICA LATINA}

\section{RESÚMEN}

Propósito: Este estudio tiene como objetivo identificar si las empresas Latinoamericanas (LA) están adoptando alguna estrategia de cobertura frente al riesgo de tipo de cambio (FXR). Para ello exploramos el impacto de varios determinantes de gestión de FXR.

Diseño/metodología: La muestra está formada por 342 empresas del sector no financiero de un grupo representativo de países latinoamericanos y abarca el período 2008 a 2016. Para testar las hipótesis se aplican modelos Logit que miden la probabilidad de adoptar diferentes prácticas de cobertura. Adicionalmente, los resultados de la aplicación de un modelo Tobit ofrecen información extra sobre los usuarios de derivados.

Hallazgos: Corroboramos las hipótesis relacionadas con la estructura de capital, tales como objetivos fiscales, dificultades financieras, liquidez y oportunidades de crecimiento. Además, tanto la concentración de propiedad como los impuestos sobre la renta por pagar parecen ser determinantes negativos y significativos de la cobertura de FXR.

Originalidad/valor: Los resultados reportados en este estudio son relevantes para la región Latinoamericana con una gran tradición en exportaciones de materias primas y productos básicos. Nuestros resultados muestran que las empresas Latinoamericanas utilizan de manera limitada los derivados y todavía hay mucho por mejorar. Por lo tanto, es deseable la promoción de esfuerzos adicionales en cuanto a la cobertura de FXR para cumplir con las recomendaciones de las autoridades (OCDE, 2007). Entre otras, serían de gran ayuda las investigaciones adicionales que exploren factores adicionales de Gobierno Corporativo (CG) así como profundizar en las diferencias entre empresas grandes y pequeñas. 
Keywords: gestión del riesgo, riesgo de tipo de cambio, cobertura, derivados, Logit, Tobit, América Latina, GIKA-LATAM-2019.

JEL: G32 


\section{Introduction}

This study investigates the main drivers of foreign exchange risk (FXR) strategies in Latin American (LA) firms. The main goal is to provide further knowledge of FXR management in emerging economies because the promotion of derivatives would be not only desirable but also necessary in the LA region, which displays high levels of raw materials and commodities exports (World Bank Group, 2018).

In the globalization era, the use of risk-coverage instruments by multinational firms is increasing at exponential rates: for the period 2004-2018 the notional trades of OTC raise their value up to $130 \%$, being interest rate and foreign exchange rate derivatives the most traded instruments, i.e. $70 \%$ and $14 \%$ on average, respectively (Bank for International Settlements, 2017; 2018).

LA countries also display a high export growth rate in commodities, i.e. 5\% from 2008 to 2016 (World Bank Group, 2018) and positive forecasts for 2018 onwards, due to: i) the strength of US demand; ii) the rise in commodity prices; and iii) favorable financial conditions for countries exporting raw materials (International Monetary Fund, 2018). In this regard, the Economic Commission for Latin America and the Caribbean (ECLAC, 2016) shows that raw materials represented up to $44 \%$ of total exports in 2016 in this region.

These export operations trigger an explicit exposure to price and FXR that firms try to avoid. In particular, FXR management raised up to $88 \%$ in the LA region between 2007 and 2016 (Bank for International Settlements, 2017), but the use of financial instruments still remains at low levels because these countries frequently face challenges associated with underdeveloped markets, limited trading options, information asymmetries and weak CG (OECD, 2007). 
Extant literature on FXR management in the LA region is scarce and academic contributions would be helpful. From the macroeconomic perspective, according to the OECD et al. (2007), the use of derivatives in emerging economies is relevant since it supports the development of capital markets by increasing investments, trading operations and asset management opportunities.

In addition, at the firm level, prior investigations reveal that hedging transactions reduce the noise and increase the informational content of the firm's profit, improving the quality of the financial forecasts (DeMarzo \& Duffie, 1995); they provide cash flow stability, because deadweight losses of bankruptcy are limited (Smith \& Stulz, 1985; Purnanandam, 2008); they are used as tax shield (Stulz, 2004) and they help to coordinate corporate investments and financing policies and to alleviate underinvestment costs (Froot, Scharfstein \& Stein, 1993).

In a nutshell, fostering the use of hedging instruments in general, and FXR hedging in particular, might contribute to the economic stability of the LA region and provide benefits to the multinational companies.

This study pretends to shed some lights into this issue. We respond to research calls (Geyer-Klingeberg, Hang, Rathgeber, Stöckl \& Walter, 2018) and extend capital structure (CS) theories by integrating corporate governance $(\mathrm{CG})$ premises. In particular, the paper at hand builds on prior contributions that identified several determinants of FXR hedging such as leverage (Smith \& Stulz, 1985; Clark \& Judge, 2008; Marshall, Kemmitt \& Pinto, 2013; Tanha \& Dempsey, 2017), tax loss carryforwards (Nance, Smith \& Smithson, 1993; Berkman \& Bradbury, 1996; Bartram, 2000), interest coverage (Clark \& Judge, 2008), or size (Ben-Zion \& Shalit, 1975; Allayannis \& Ofek, 2001; Marshall et al., 2013); among others. Noteworthy, in the LA region, we are only aware of the study by Schiozer and Saito (2009). 
This paper investigates the main factors associated with FXR management strategies in a sample of non-financial firms listed on the main stock exchanges in Argentina, Brazil, Chile, Colombia, Mexico, and Peru, from 2008 to 2016.

We contribute to previous knowledge in several ways. Firstly, we extend the range of countries analyzed in Schiozer and Saito (2009) by including not only Chile, Brazil, Mexico, and Argentina but also Peru and Colombia. After the worldwide financial crisis of 2008, the economies that show the highest GDP growth rate in South America are Peru, Brazil, and Colombia with an average rate of $6 \%, 4 \%$ and $3 \%$ respectively (World Bank, 2018). Therefore, by including Peru and Colombia the study covers around $99 \%$ of the market capitalization of listed domestic companies of both the LA and the Caribbean regions (World Bank, 2018) and offers an extended geographical analysis.

Secondly, we find that previous literature (Allayannis, Lel, \& Miller, 2012) examines the impact of derivatives in the firm's value for a sample of companies and listed in the U.S. exchanges. Alternatively, this study provides evidence on the FXR hedging strategies followed by LA firms listed in their domestic markets.

Thirdly, in our view, this study updates prior results since Lel (2012) covers the 19901999 period and Schiozer and Saito (2009)'s data starts in 2001 and finishes in 2004. We investigate a recent period of time (2008-2016) because from 2004 several LA countries have implemented domestic financial markets, i.e. from 2009 the future contracts are traded in the centralized markets in Colombia.

In addition, LA firms have recently experienced severe changes in their managerial and governance culture, both in governmental and non-governmental companies (Banco de Desarrollo de América Latina, 2012), being the case of the mining companies ISAGEN (Colombia) and CODELCO (Chile), the Panama Channel (Panamá) or the public services EPM 
(Colombia). In addition, our period of study is characterized by high currency volatility: According to the World Bank (2018), for the period 2014-2016, LA countries exhibit a nominal depreciation of their currencies in relation to the US dollar (33.1\% in the case of Argentina) when FXR becomes even more relevant.

Finally, Schiozer and Saito (2009) only explore financial theory-based hypotheses, but we also integrate governance motivations for FXR practices, in order to provide a wider perspective.

The rest of the paper is organized as follows. Section 2 describes the literature review and development of the hypotheses to be tested. Section 3 reports the methodological design of the research, sample construction, and descriptive results. Section 4 includes the empirical and robustness tests, and in Section 5 we discuss our findings and conclude.

\section{Literature review and hypotheses development}

This study integrates two theoretical frameworks, namely, the CS theory and the agency theory. Following, we describe these theories that provide the premises for our research hypotheses.

\subsection{Hypotheses developed under the Capital Structure Theory}

According to the CS theory by Modigliani \& Miller (1958) in a perfect market the firm's CS is irrelevant and companies do not need to manage risk because it does not affect the firm value. However, since in the real world those conditions of perfect competition do not hold, CS scholars aim to identify the CS and risk strategies that maximize firm value and explore 
additional factors such as hedging activities, transaction costs, bankruptcy costs, or tax functions, among others.

Within the CS framework, we rely on the trade-off (TO) theory that integrates tax considerations. The TO theory postulates that a firm reaches the optimum equilibrium (maximum firm value) when the leverage ratio triggers the maximum tax benefits with the minimum insolvency risk (Kraus \& Litzenberger, 1973; Kim, 1978; Myers, 1984; Bradley, Jarrell \& Kim, 1984).

Prior investigations under the TO theory have explored the relationship between hedging decisions, CS and tax factors and their impact on the firm value. Some academics report that hedging increases firm value (Graham \& Rogers, 2002; Faff \& Marshall, 2005; Carter, Rogers \& Simkins, 2006; Bartram, Brown \& Conrad, 2011; Giraldo-Prieto, González Uribe, Vesga Bermejo \& Ferreira Herrera, 2017). Conversely, other researchers report that derivatives reduce FXR but fail to prove value creation (Belghitar, Clark, \& Mefteh, 2013). Hence, empirical evidence is not conclusive. Following, we develop the hypotheses related to TO theory.

\section{Corporate taxes as determinants of hedging activities}

According to Smith and Stulz (1985), if a firm faces a convex tax function (i.e. taxes increase over-proportionally with taxable income), corporate hedging can increase post-tax firm value by reducing the volatility of pre-tax income. Several empirical contributions (Nance et al.,1993; Berkman \& Bradbury, 1996; Bartram, 2000) demonstrate this premise. In consequence, the use of derivatives might be employed as a tax shield (Stulz, 2004).

The survey by Brown (2001) reveals that decreasing the expected US taxes is not a motivation for treasurers and tax experts to hedge. In this vein, Haushalter (2000) argues that 
the company's marginal tax rate provides little support for a tax-based explanation for hedging. Graham and Rogers (2002); Schiozer and Saito (2009) and Marshall et al. (2013) also fail to corroborate that firms hedge in response to tax convexity or to decrease expected taxes.

However, although the tax-based forces for hedging cast doubts, the association between income tax payable and hedging activities rise fewer concerns: Barton (2001) and Donohoe (2015) prove that, on average, derivatives users pay fewer taxes than non-users do. Moreover, Graham and Rogers (2002) demonstrate that hedging increases debt capacity and increase tax benefits by $1.1 \%$ of firm value.

Therefore, based on prior evidence, we posit the following hypothesis:

H1: Income tax payable is negatively associated, ceteris paribus, to the likelihood of FXR hedging.

\section{Financial distress costs as determinants of hedging activities}

Smith and Stulz (1985) argued that the avoidance of transaction costs related to financial distress (such as higher debt costs, guarantees and collaterals) can induce firms to hedge and avoid risks. In this sense, Judge (2006) posits that the higher the firm's indebtedness, the lower the interest coverage ratio (ICR), the greater probability of financial distress and, thus, the higher probability of risk hedging. Nevertheless, opposite reasoning may apply: Berkman and Bradbury (1996) claim that if hedging allows the firm to increase debt capacity and raise funds at a lower cost, then ICR should decrease and the firm should be less financially distressed. But, then, the firm would face less incentive to hedge (Schiozer \& Saito, 2009). 
Since no conclusive results from individual studies have been reported yet, the relationship among leverage, ICR, default probability and risk-avoidance strategies should be empirically determined.

Haushalter (2000) documents that FXR hedging could minimize debt costs and improve the terms of the financial debt contracts and, eventually, be positively associated with leverage. Similarly, Chen and Dolly K. (2014) report strong evidence that hedging is associated with a lower cost of debt.

Clark and Judge (2008) divide the group of FXR hedgers into derivatives users and firms that use foreign currency debt in the same currency as future foreign earnings. Leverage variables are significantly related to FXR hedgers that use both methods but not to those firms that only use derivatives.

Moreover, the TO theory predicts that leverage should increase with tax benefits (Otero González, Vivel Búa, Fernández López \& Durán Santomil, 2010). Accordingly, hedging strategies would ease higher leverage and higher tax benefits, as documented by Lel (2012) and Graham and Rogers (2002). However, Lel (2012) confirmed Clark and Judge (2008) conclusions on the lack of association between the use of FX derivatives and leverage.

Additionally, the institutional context is relevant because financial distress costs are less pronounced for the US than for non-US firms (Geyer-Klingeberg et al., 2018).

Based on theoretical and empirical findings, we posit the following hypotheses in the same direction that have predominantly been tested, according to the meta-data provided by Geyer-Klingeberg et al. (2018):

H2a: Leverage is positively associated, ceteris paribus, to the likelihood of FXR hedging H2b: ICR is negatively associated, ceteris paribus, to the likelihood of FXR hedging 


\section{Liquidity as a determinant of hedging activities}

Liquidity represents the ability of a firm to fully meet its short-term contractually fixed payment obligations (Géczy, Minton, \& Schrand, 1997).

Nance et al. (1993) posit that liquidity is a substitute for hedging and that FXR derivatives users involve significantly less liquid assets and higher dividend yields (Froot et al., 1993; Marshall et al., 2013).

In LA countries, Schiozer and Saito (2009) report that derivatives and liquidity are almost unrelated.

The meta-analysis by Geyer-Klingeber et al. (2018) identifies liquidity as one of the variables negatively and significantly associated with corporate hedging decisions. In spite of these findings, Gamba and Triantis (2013) theoretically demonstrate that high levels of cash play an important role in risk management. In this vein, Mello and Parsons (2000) argue that optimal coverage maximizes the company's liquidity-slack in terms of excess cash or unused debt capacity when liquidity is more valuable, so hedge can also be understood as a source of liquidity to the firm.

Since prior archival findings are not conclusive, we posit the following hypothesis:

H3: Liquidity is negatively or positively associated, ceteris paribus, to the likelihood of FXR hedging

\section{Investment opportunities as determinants of hedging activities}

Currencies' volatility may lead to discard projects with negative present values that should be profitable, provided FXR is covered. Then, managers face incentives to hedge FXR associated to investments. Moreover, Froot et al. (1993) theoretically demonstrate that, when 
external funds are costlier than internally generated funds, then risk management may assure internal funds to finance good investment opportunities. Then, investment and growth opportunities represent a good driver for hedging. However, Lin, Phillips and Smith (2008) state that the way in which hedging affects the firms' financing and investing decisions differs across firms with different growth opportunities.

In this regard, Choi, Maoand and Upadhyay (2013) assert that R\&D projects can also benefit from risk coverage through corporate hedging and mitigate underinvestment problems. However, Géczy et al. (1997) failed to find any significant association between R\&D and the use of currency derivatives.

The overall conclusion from prior empirical literature is that the degree of investment and growth opportunities is not a robust determinant of hedging activities and that the relationship between R\&D expenses and hedging decreases over time (Geyer-Klingeberg et al., 2018).

In emergent countries growth opportunities through tangible assets are higher than in developed countries, thus we expect to prove the following hypothesis in the LA region:

H4: Investment opportunities are positively associated, ceteris paribus, to the likelihood of FXR hedging.

\subsection{Hypotheses developed under the Agency theory and using CG mechanisms}

Within the agency theory (Jensen \& Meckling, 1976; Fama \& Jensen, 1983), CG mechanisms are aimed at mitigating agency costs, such as the information asymmetries and the divergence of principal-agent interests (and/or the alternate agency relationships). 
Hence, governance improvements in emerging markets benefit firms through better financial strategies and better financial performance where CG challenges (including the firm's ownership structure) are highly influenced by the institutional environment (Claessens \& Yurtoglu, 2013). Additionally, shareholders can use corporate financial policies such as hedging to complement their governance mechanisms (Lel, 2012).

According to (La Porta, Lopez-de-Silanes, Shleifer, and Vishny (1998, 2000), in commonlaw countries, the shareholder protection is high and large companies are traditionally listed in stock markets with their ownership being highly disseminated. However, in other legal systems, firms exhibit a high degree of ownership concentration (Cuervo, 2002). Those shareholders with a high proportion of shares (at least five per cent of a firm's outstanding shares), known as blockholders, often have a strong presence in the board of directors and can play an active monitoring role (Almazan, Hartzell \& Starks, 2005; Jensen \& Warner, 1988; López-Iturriaga, García-Meca \& Tejerina-Gaite, 2015). They have more incentives to do so because they are bearing risk in huge investments; they can be more effective at overcoming the free-rider problem caused by ownership dispersion and, proportionally, their monitoring costs become lower.

Then, in highly concentrated ownership firms, it is plausible to expect that board of directors play a stronger monitoring role over managers and that managers will be more conservative in risk terms. DeMarzo and Duffie (1995) claim that good governance influences hedging decisions, which helps to mitigate information asymmetries, to reduce the noise and to increase the informational content of the firm's profit, improving the quality of the financial forecasts. They find that the use of derivatives to hedge FXR is related to strongly governed firms and is included in the corporate risk strategy, while weakly governed firms appear to use derivatives mostly for managerial reasons. 
However, to our knowledge, the empirical evidence on this ground is limited. Regarding the type of blockholder, Géczy, Minton, and Schrand (1997) demonstrate that firms with high institutional ownership are more likely to hedge with currency derivatives. Tungsong and Jiraporn (2016) indicate that family ownership by itself does not have a significant impact on the Thai firm's propensity to hedge; only when family members have a strong presence on the board of directors, firms are significantly more likely to engage in hedging activities.

LA companies exhibit high ownership concentration in the hands of families, banks and other large companies (Black, de Carvalho, Khanna, Kim \& Yurtoglu, 2017; Claessens \& Yurtoglu, 2013). Cid, Jara, Maquieira, and San Martín (2017) reveal a U-inverted relationship between the use of derivatives and the firm's value in Chile, so the positive association between FXR coverage and firm's value turns out to be negative when the ownership concentration exceeds the maximum. Thus, considering that ownership concentration in LA firms is high and based on prior evidence (Cid et al., 2017) we expect a negative association between ownership concentration and risk avoidance strategies and, accordingly, we posit the following hypothesis:

H5: Ownership concentration is negatively associated, ceteris paribus, to the likelihood of FXR hedging

The agency theorists advocate that the optimal contract is the one that links executive compensation with firm performance, controlling for firm risk measures, because it closely aligns the interests of shareholders (principal) and the managers (agent) and, consequently, it reduces agency problems (Jensen \& Murphy, 1990).

In the aftermaths of several financial scandals (Enron, Parmalat, Bankia, among others), society and academics claimed that executive remuneration seemed to be excessive and failurerewarding (De Andrés, Reig, \& Vallelado, 2019). In response to the social claim, several 
authorities and standard setters (Section 952 of the Dodd-Frank Act of 2010; the 2010 UK Governance; the EU Directive 2013/36/E) prompted the implementation of the payperformance scheme with a variable component of the salary linked to the firm's performance (bonuses, stock options, among others). Hence, managers face high incentives to avoid unnecessary or excessive risks when their salaries include a variable component of the salary.

Prior research corroborates this assertion. Barton (2001) evidences the managerial use of derivatives and discretional accruals as substitutes to manage earnings volatility and the effect of the governance on this interaction. Tufano (1996) and Dionne and Triki (2013) prove this positive association between managerial shareholdings and hedging activities. Graham and Rogers (2002) report that managers show risk aversion (including Vega per option as a measure of the option's price sensitivity to changes in the volatility of the underlying asset) when it benefits CEO's salaries and bonuses. Marshall et al. (2013) tested a number of remuneration variables, but only the variable related to shares owned by executive directors turned out to be significant to hedging strategies.

Related to the stock option compensation, Rajgopal and Shevlin (2002) report that executive stock option sensitivity to stock return volatility is associated with less hedging in price risk exposure.

Hence, based on prior evidence, we predict a positive influence of the manager's remuneration and hedging activities, thus, we posit the following hypothesis:

H6: Stock option compensation expenses are positively associated, ceteris paribus, to the likelihood of FXR hedging 


\section{Empirical design}

\section{1. $\quad$ Research methodology}

We use panel-data econometrics on a data panel strongly balanced, with 342 nonfinancial firms listed in the period 2008-2016 (3,078 observations). Following prior validated methodology (Nance et al., 1993; Allayannis \& Ofek, 2001; Clark \& Judge, 2008; Otero González et al., 2010), we developed a Logit model (Equation I) to identify whether the explanatory variables increase the likelihood for the firm to hedge FXR (the dependent variable equals 1 ) or not (the dependent variable equals 0 ):

$$
\begin{gathered}
\operatorname{Pr}(F X R H=1)=\alpha+\beta_{1} \text { ITP }_{i t}+\beta_{2} \text { Leverage }_{i t}+\beta_{3} \text { ICR }_{i t}+\beta_{4} \text { Quick }_{i t}+\beta_{5} \text { Capex }_{i t}+\beta_{6} \text { Owner }_{i t} \\
+\beta_{7} \text { Stock }_{-} \text {Comp }_{i t}+\beta_{8} \text { Size }_{i t}+\beta_{9} \text { FXR_index }_{i t}+\beta_{10} \text { DeltaFX }_{i t}+\varepsilon_{i t}
\end{gathered}
$$

Where, the dependent variable, $\operatorname{Pr}(F X R H)$ is the likelihood for the firm to hedge FXR exposure. To further explore different FXR management strategies, we develop three models: First, the dependent variable $\operatorname{Pr}\left(F X R_{-} A A\right)$ in Model 1 captures the probability for the company to hedge FXR, through accounting measures and/or derivatives. Secondly, $\operatorname{Pr}\left(F X R H \_d e\right)$ in Model 2, identifies the likelihood to hedge FXR with derivatives, at least, one year during the period of analysis. Finally, $\operatorname{Pr}\left(F X R H \_d e \_r e g\right)$ in Model 3 represents the probability for the company to cover FXR with derivatives on a regular basis (i.e., the use of derivatives covers, at least, 4 out of the 9 years of our period of analysis).

The set of explanatory variables are the following: We estimate whether the firm is obtaining tax benefits through the variable income tax payable (ITP) scaled with total assets 
(Nance et al., 1993; Judge, 2006; Clark \& Judge, 2008; Otero González et al., 2010; Donohoe, 2015) Following prior research (Clark \& Judge, 2008; Marshall, Kemmitt, \& Pinto, 2013; Tanha \& Dempsey, 2017), Leverage is estimated as the book value of debt over the market value of the company. We measure ICR through the EBIT over interest expenses (Berkman \& Bradbury, 1996; Clark \& Judge, 2008) to estimate the firm's capacity to pay back the financial costs of the debt. As in Berkman and Bradbury (1996) and Géczy et al. (1997), we estimate firms' liquidity through the quick ratio (Quick) calculated as the current assets less inventories over the current liabilities. We approach investment and growth opportunities through capital expenditures, Capex, i.e. funds used to acquire fixed assets and other than those associated with acquisitions, in its log form (Geyer-Klingeberg et al. 2018).

Regarding CG characteristics, Ownership is the percentage of shares owned by the shareholder who has the majority of the voting rights, veto power or golden share. Stock_comp is the natural $\log$ of the provision for stock option compensation released in the profit and loss account. Following Marshall et al. (2013), when the stock option compensation is not reported net of taxes, the standard tax rate is applied to the reported pre-tax amount.

We also control for several factors that, according to prior research, are likely to influence FXR exposure hedging. Firstly, we control for company's size (Size) because, as stated by Faff and Marshall (2005), larger companies are expected to make more foreign operations, face higher FXR exposure and, eventually, use derivatives in a greater extent. In addition, most of the costs associated with risk management are fixed rather than variable, such as specialized personnel and software, that make small contracts uneconomical. Thus, there are economies of scale associated with risk management using derivatives which implies a positive relationship between firm size and derivatives usage, as reported by the vast majority of archival research (Geyer-Klingerberg et al., 2018). Hence, we expect for this variable a positive sign and it is measured through the natural log of the total assets at year-end. 
Additionally, we expect that the higher the FXR exposure level the higher the use of hedging instruments. Thus, to control for the firm's exposure level, we estimate an index, labeled FXR_index, which consists of the mean value of the outcome of adding the following two items for each firm every year: i) the proportion of foreign assets to total assets; and ii) the proportion of foreign sales to total sales (Allayannis \& Ofek, 2001; Belghitar, Clark, \& Mefteh, 2013; Jin \& Jorion, 2006; Lel, 2012). Finally, we control for DeltaFX, which measures the volatility in the absolute value of the currencies analyzed. We do not expect a specific sign for this variable.

We work with positive values in all variables to estimate panel data Logit models. Descriptions of the variables, their measurements, and the expected sign are displayed in the Appendix.

\subsection{Sample of the study}

The sample includes non-financial firms listed in the stock exchanges of Argentina, Brazil, Chile, Colombia, Mexico, and Peru and it covers from 2008 to 2016. The period of analysis starts in 2008 because it is the year from which we were able to obtain reliable data on FXR hedging practices in LA. We used two sources of information: i) Thomson DataStream and Economática databases; ii) additional information regarding FXR and hedging practices were manually collected from the annual reports released in companies' web sites or, alternatively, in their respective Financial Supervisory Authority web sites.

Following Clark and Judge (2008), Géczy et al. (1997), and Graham and Rogers (2002), the sample only includes firms that are exposed to FXR; that is, that are disclosing one or several of the following items in their annual accounts: i) foreign sales; ii) foreign taxes; iii) FX transactions; iv) foreign assets;; and v) qualitative discussion related to FXR in the notes. 
Table 1 discloses the distribution of the final sample (which consists of 342 companies and 3,078 firm-year observations) by country. In 1,192 observations, LA firms do not cover FXR, meanwhile, in 1,886 cases firms practice operational and/or financial coverage. In 1,693 out of 1,886 cases $(55 \%)$, firms have engaged in derivatives transactions and in 877 out of 1,886 cases $(28.49 \%)$ they do it regularly. Brazil provides the highest number of companies (132) which represents $38.60 \%$ of the sample, followed by Chile (76 firms), Mexico (51 firms), Argentina (33 firms), Peru (34 firms), and Colombia in the last place with 16 companies. Regarding FXR management, Brazilian companies display the highest use of derivatives, either sporadically $(36.68 \%)$ or regularly $(34.09 \%)$. This proactive attitude towards exchange risk is followed by Chile and Mexico with 282 and 228 cases of regular use of derivatives, respectively. Conversely, none of the companies in Colombia uses derivatives regularly.

\section{[Insert Table 1 about here]}

\subsection{Descriptive results}

Table 2 shows the descriptive statistics of the variables considered in the study. Average data related with the whole sample (column 1, Table 2 ) indicates that $61.3 \%$ of the exposed firms to FXR did manage this risk through accounting compensation and/or with derivatives $\left(F X R H_{-} A A=1\right)$. Around $55 \%$ of the sample used derivatives, at least, one year during the analyzed period $\left(F X R H \_d e=1\right)$ and only $28 \%$ of the sample used derivatives, at least for 4 years $\left(F X R H \_d e \_r e g=1\right)$.

Noteworthy, ITP in LA firms is around 1\%, leverage offers an average value of $81.9 \%$ and Ownership varies from $1.5 \%$ to $99.9 \%$, but, on average is about $40 \%$. 
[Insert Table 2 about here]

In order to assess whether there is any statistical difference between our groups of observations, we perform a standard t-test (T-student) and report the results in Table 3.

[Insert Table 3 about here]

Regarding our variables of interest, according to H1, those firms that are covering FXR and that use derivatives regularly are disclosing less ITP than the remaining firms do (this variable displays negative and significant coefficients in columns 3 and 9 of Table 3). Leverage, Capex and Stock_comp variables present positive coefficients, therefore, hedgers exhibit higher indebtedness, growth and executive stock compensation than non-hedgers do (according to $\mathrm{H} 2 \mathrm{a}, \mathrm{H} 4$, and H6). ICR only displays the expected sign (H2b) at $1 \%$ level for those companies that use derivatives regularly (column 9). Quick(H3) presents miscellaneous results. Ownership exhibits a negative coefficient, as expected according to H5, but it turns out to be significant only when comparing firms that do hedge with those firms that do not. Finally, the control variables are significant and display the expected sign according to prior investigations.

In order to detect multicollinearity problems, we perform the Bonferroni correlation analysis for significance levels of 5\% or less. Marshall et al. (2013), consider as significant evidence of multicollinearity a 0.8 cut-off coefficient correlation value. We run the Dunn-Sidak adjustment at 5\%. In our sample, results (unreported) do not exhibit severe multicollinearity problems. 


\section{Results}

\subsection{Results of the logistic regressions}

Table 4 reports the results of the logistic regression for the three models where the dependent variable is FXRH_AA (Model 1); FXRH_de (Model 2); and FXRH_de_reg (Model 3), which captures the likelihood for adopting any FXR coverage measure, hedging with derivatives and hedging with derivatives on a regular basis, respectively. For every group, we have run the extended model with all explanatory variables, and also the CS removed and the $C G$ removed models where the $\mathrm{CS}$ and the $\mathrm{CG}$ variables are dropped, respectively.

[Insert Table 4 about here]

Notably, all models display high predictive power by around $73 \%$. The chi ${ }^{2}$ tests reveal that including the CS and CG variables in the extended models significantly (at 1\%) increases the explanatory power. Hence, for the sake of brevity, we only comment below on the extended models.

Regarding CS variables, our results corroborate H1 because the likelihood of adopting FXR coverage is negatively associated with the amount of income tax payable (ITP). Leverage is statistically significant with a positive sign for derivatives users, either under isolated or regular use, confirming $\mathrm{H} 2 \mathrm{a}$. Noteworthy, in Model 1, that also comprises accounting FXR hedging, the variable is not significant. The ICR reports statistical coefficients but with different signs, i.e. positive in Model 1 and Model 2 but negative in Model 3. Quick displays a significant coefficient in Model 2 (10\% of significance) and in Model 3 (1\% of significance) with a positive sign. Capex shows significant and positive coefficients in every model, thus we can confirm H4. Regarding CG variables, only Ownership displays negative and significant 
results in every model, as expected (H5). Hence, we fail to confirm H6. All control variables are significant at $1 \%$ and display the same sign than expected.

\subsection{Further insights into the derivatives users}

To further explore the extent of FXR hedging through the use of derivatives, we also run a panel data Tobit model (as in Brunzell, Hansson \& Liljeblom, 2011; Afza \& Alam, 2011; Lel, 2012; Tanha \& Dempsey, 2017) controlling for the unobserved heterogeneity with random and fixed effects to estimate the magnitude of hedging through derivatives (Schiozer \& Saito, 2009) on the same data used in the logistic regressions. The Tobit model (displayed in Table 5) considers the same set of independent variables disclosed in Equation I, where the dependent, now continuous, variable captures the proportion of derivatives to some items of the annual accounting statements, in particular: i) DERIV_ASSET equals to current assets derivatives plus non-current assets derivatives over total assets (Model 4); ii) DERIV_LIAB equals to current liabilities derivatives plus non-current liabilities derivatives over total debt (Model 5), and iii) DERI_CFLW equals the absolute value of derivatives unrealized gain or losses in hedging positions over EBIT (Model 6). Lower and upper limits are censored at the 95\% level.

The three models display a negative association between the dependent variable and ITP (H1). Variables related to the financial distress hypothesis ( $\mathrm{H} 2 \mathrm{a}$ and $\mathrm{H} 2 \mathrm{~b})$, i.e. Leverage and $I C R$, are not significant. Quick (H3) and Capex (H4) are positively associated with the percentage of liabilities derivatives. The results corroborate H5 only for assets derivatives (Model 4) because Ownership exhibits significance at 1\%. To sum up, hypotheses testing through the Tobit models do not offer robust results but income taxes payable (ITP).

[Insert Table 5 about here] 


\subsection{Additional analysis}

We split the sample into large and small firms (above and below mean Size) and the results (untabulated) indicate that the model performs better with smaller firms than with larger firms.

We also test whether the model is sensitive to alternate measures of our variables of interest. The untabulated results confirm that ITP is negatively associated with hedgers and occasional derivatives users. We also employ lagged ITP, in order to deal with endogeneity concerns, and the sign and significance remain the same. Regarding leverage ratios, we also find a positive association between FX debt and hedging for all models at $1 \%$ of significance. We also replaced Quick with the current ratio (current assets to current liabilities) and results were significantly positive for all models. An alternate measure of growth opportunities, that is, $R \& D$ expenses, displays significant but negative coefficient.

\section{Discussion of the findings, conclusions, and limitations of the study}

\section{Discussion of the findings}

This study updates previous empirical research by Schiozer and Saito (2009) and Lel (2012) although relevant differences in the methodology and the sample prevent us from direct comparisons. Firstly, we have tested the likelihood to carry out any type of FXR coverage, that is, operational and with derivatives. However, our model performs better for the regular derivatives users, the main focus of the Shiozer and Saito (2009) study. Similar to the abovementioned authors and Graham and Rogers (2002), we confirm that avoidance of transaction costs associated with financial distress and investment opportunities are relevant forces of derivatives usage. On the contrary, the cited references fail to prove any tax benefit 
from FXR hedging; meanwhile, we report a negative association between FXR coverage and income tax payable.

Moreover, our results corroborate the CS related hypotheses, because leverage and growth are positively associated with the likelihood of FXR hedging and, in particular, with the regular use of derivatives.

On the other hand, LA countries exhibit a high ownership concentration and, according to our results, this concentration negatively influences FXR hedging, in the same vein than prior evidence from Chile (Cid et al., 2017).

\section{Concluding remarks and limitations of this research}

This paper investigates the main determinants of FXR management in six LA countries, namely Argentina, Brazil, Chile, Colombia, Mexico, and Peru, through a data panel strongly balanced comprising 342 non-financial firms listed in their respective main stock exchanges in the period 2008-2016.

Firstly, our data evidence that there is a significant gap in FXR management among the countries of the sample. On the one hand, Brazil and Chile seem to be the most advanced in FXR management because they display the highest levels of both, coverage and derivatives usage. Conversely, Argentina and Colombia display the lowest levels of FXR coverage, being null the use of derivatives on a regular basis by Colombian firms.

The multivariate results suggest that LA firms are considering tax benefits and financial distress costs when adopting FXR management decisions. Liquidity is also positively associated with the likelihood of FXR hedging. We also conclude that firms that are investing 
in fixed assets are more likely to hedge FXR but we failed to prove any association with R\&D expenses.

Noteworthy, ownership concentration is negatively associated with the likelihood of FXR hedging, as Cid et al. (2017) report for Chile. The results are robust to several sensitivity analyses. Hence, further investigation on the type of blockholder and/or alternate CG variables and theories would be desirable.

Among the limitations of this study, we reckon those that apply to most archival research, that is, that our experimental variables that are significant might reflect the effect of omitted correlated variables. Furthermore, it is worth mentioning that the tested models lack from non-identified country-level variables that might explain our main results.

In addition, alternate theoretical CG frameworks, such as the Stewardship or the Stakeholder theories might better illustrate the LA governance culture and family ownership (Briano-Turrent \& Poletti-Hughes, 2017). Finally, it seems that there are major differences between large and small firms in LA, and therefore further research on this topic would be desirable for the development of financial strategies. 
[Insert Appendix about here] 


\section{REFERENCES:}

Afza, T., \& Alam, A. (2011). Determinants of extent of financial derivative usage. African Journal of Business Management, 5(20), 8331-8336. https://doi.org/10.5897/AJBM11.930

Allayannis, G., Lel, U., \& Miller, D. P. (2012). The use of foreign currency derivatives, corporate governance, and firm value around the world. Journal of International Economics, 87(1), 65-79. https://doi.org/10.1016/j.jinteco.2011.12.003

Allayannis, G., \& Ofek, E. (2001). Exchange rate exposure, hedging, and the use of foreign currency derivatives. Journal of International Money and Finance, 20(2), 273-296. https://doi.org/10.1016/S0261-5606(00)00050-4

Almazan, A., Hartzell, J., \& Starks, L. (2005). Active institutional shareholders and costs of monitoring: evidence from executive compensation. Financial Management, 34(4), 534. https://doi.org/10.1111/j.1755-053X.2005.tb00116.x

Banco de Desarrollo de América Latina, Bernal, A., Oneto, A., Penfold, M., Schneider, L., \& Wilcox, J. (2012). Gobierno corporativo en América Latina. Importancia para las empresas de propiedad estatal. Serie Políticas Públicas y Transformación Productiva, (6), 1-80. Retrieved from http://www.oecd.org/daf/ca/secondmeetinglatinamericasoenetworkcafwhitepaperspanish. pdf

Bank for International Settlements. (2017). Triennial survey of foreign exchange and OTC derivatives trading. Basel, Switzerland. Retrieved from https://www.bis.org/statistics/about_derivatives_stats.htm?m=6\%7C32\%7C639

Bank for International Settlements. (2018). OTC derivatives outstanding. Basel, Switzerland. 
Retrieved from https://www.bis.org/statistics/derstats.htm?m=6\%7C32\%7C71

Barton, J. (2001). Does the use of financial derivatives affect earnings management decisions? The Accounting Review, 76(1), 1-26.

https://doi.org/https://dx.doi.org/10.2139/ssrn.206869

Bartram, S. M. (2000). Corporate risk management as a lever for shareholder value creation. Financial Markets, Institutions \& Instruments, 9(5), 279-324. https://doi.org/10.1111/1468-0416.00038

Bartram, S. M., Brown, G. W., \& Conrad, J. (2011). The effects of derivatives on firm risk and value. The Journal of Financial and Quantitative Analysis, 46(4), 967-999. https://doi.org/10.1017/S0022109011000275

Belghitar, Y., Clark, E., \& Mefteh, S. (2013). Foreign currency derivative use and shareholder value. International Review of Financial Analysis, 29, 283-293. https://doi.org/10.1016/j.irfa.2012.02.004

Ben-Zion, U., \& Shalit, S. S. (1975). Size, leverage, and dividend record as determinants of equity risk. The Journal of Finance, 30(4), 1015-1026. https://doi.org/https://doi.org/10.2307/2326720

Berkman, H., \& Bradbury, M. E. (1996). Empirical evidence on the corporate use of derivatives. Financial Management, 25(2), 5-13. https://doi.org/10.2307/3665985

Bessembinder, H. (1991). Forward contracts and firm value: investment incentive and contracting effects. The Financial and Quantitative Analysis, 26(4), 519-532. https://doi.org/10.2307/2331409

Black, B., de Carvalho, A. G., Khanna, V., Kim, W., \& Yurtoglu, B. (2017). Corporate 
governance indices and construct validity. Corporate Governance: An International Review, 25(6), 397-410. https://doi.org/10.1111/corg.12215

Bradley, M., Jarrell, G. A., \& Kim, E. H. (1984). On the existence of an optimal capital structure: theory and evidence. The Journal of Finance, 39(3), 857-878. https://doi.org/10.2307/2327950

Briano-Turrent, G. del C., \& Poletti-Hughes, J. (2017). Corporate governance compliance of family and non-family listed firms in emerging markets: Evidence from Latin America. Journal of Family Business Strategy, 8(4), 237-247. https://doi.org/10.1016/j.jfbs.2017.10.001

Brown, G. W. (2001). Managing foreign exchange risk with derivatives. Journal of Financial Economics, 60(2), 401-448. https://doi.org/10.1016/S0304-405X(01)00049-6

Brunzell, T., Hansson, M., \& Liljeblom, E. (2011). The use of derivatives in Nordic firms. European Journal of Finance, 17(5-6), 355-376. https://doi.org/10.1080/1351847X.2010.543836

Carter, D. A., Rogers, D. A., \& Simkins, B. J. (2006). Does hedging affect firm value? Evidence from the US airline industry. Financial Management, 35(1), 53-86. https://doi.org/10.1111/j.1755-053X.2006.tb00131.x

Chen, J., \& Dolly King, T.-H. (2014). Corporate hedging and the cost of debt. Journal of Corporate Finance, 29, 221-245. https://doi.org/10.1016/j.jcorpfin.2014.09.006

Choi, J. J., Mao, C. X., \& Upadhyay, A. D. (2013). Corporate risk management under information asymmetry. Journal of Business Finance and Accounting2, 40(1, 2), 239271. https://doi.org/https://doi.org/10.1111/jbfa.12008 
Cid Aranda, C., Jara Bertín, M., Maquieira Villanueva, C., \& San Martín Mosqueira, P. (2017). Instrumentos derivados, concentración de propiedad y valor de la firma.

Evidencia para Chile. El Trimestre Económico, 84(336), 947-974.

https://doi.org/10.20430/ete.v84i336.611

Claessens, S., \& Yurtoglu, B. B. (2013). Corporate governance in emerging markets: a survey. Emerging Markets Review, 15, 1-33.

https://doi.org/10.1016/J.EMEMAR.2012.03.002

Clark, E., \& Judge, A. (2008). The determinants of foreign currency hedging: does foreign currency debt induce a bias? European Financial Management, 14(3), 445-469. https://doi.org/10.1111/j.1468-036X.2007.00360.x

Cuervo, A. (2002). Corporate governance mechanisms: A plea for less code of good governance and more market control. Corporate Governance: An International Review, 10(2), 84-93. https://doi.org/10.1111/1467-8683.00272

De Andrés, P., Reig, R., \& Vallelado, E. (2019). European banks' executive remuneration under the new European Union regulation. Journal of Economic Policy Reform, 22(3), 208-225. https://doi.org/10.1080/17487870.2018.1424630

DeMarzo, P. M., \& Duffie, D. (1995). Corporate incentives for hedging and hedge accounting. Review of Financial Studies, 8(3), 743-771. https://doi.org/10.1093/rfs/8.3.743

Dionne, G., \& Triki, T. (2013). On risk management determinants: what really matters? The European Journal of Finance, 19(2), 145-164.

https://doi.org/10.1080/1351847X.2012.664156 
Donohoe, M. P. (2015). The economic effects of financial derivatives on corporate tax avoidance. Journal of Accounting and Economics, 59(1), 1-24. https://doi.org/10.1016/j.jacceco.2014.11.001

Economic Commission for Latin America and the Caribbean (ECLAC). (2016). Statistical Yearbook for Latin America and the Caribbean. Retrieved from https://repositorio.cepal.org/bitstream/handle/11362/40972/4/S1601037_mu.pdf

Faff, R. W., \& Marshall, A. (2005). International evidence on the determinants of foreign exchange rate exposure of multinational corporations. Journal of International Business Studies, 36(5), 539-558. https://doi.org/10.1057/palgrave.jibs.8400155

Fama, E. F., \& Jensen, M. C. (1983). Corporations and private property: a conference sponsored by the Hoover Institution. Journal of Law and Economics, 26(2), 301-325. https://doi.org/https://doi.org/10.1086/467037

Froot, K. A., Scharfstein, D. S., \& Stein, J. C. (1993). Risk management: coordinating corporate investment and financing policies. The Journal of Finance, 48(5), 1629-1658. https://doi.org/10.1111/j.1540-6261.1993.tb05123.x

Gamba, A., \& Triantis, A. J. (2013). Corporate risk management: integrating liquidity, hedging, and operating policies. Management Science, 60(1), 246-264. https://doi.org/https://doi.org/10.1287/mnsc.2013.1752

Gay, G. D., \& Nam, J. (1998). The underinvestment problem and corporate derivatives use. Financial Management, 27(4), 53-69. https://doi.org/10.2307/3666413

Géczy, C., Minton, B., \& Schrand, C. (1997). Why firms use currency derivatives. The Journal of Finance, 52(4), 1323-1354. https://doi.org/10.1111/j.1540- 
6261.1997.tb01112.x

Geyer-Klingeberg, J., Hang, M., Rathgeber, A. W., Stöckl, S., \& Walter, M. (2018). What do we really know about corporate hedging? A meta-analytical study. Business Research, 11(1), 1-31. Retrieved from http://10.0.3.239/s40685-017-0052-0

Giraldo-Prieto, C. A., González Uribe, G. J., Vesga Bermejo, C., \& Ferreira Herrera, D. C. (2017). Financial hedging with derivatives and its impact on the Colombian market value for listed companies. Revista Contaduria y Administracion, 62(5), 1572-1590. https://doi.org/http://dx.doi.org/10.1016/j.cya.2017.04.009

Graham, J. R., \& Rogers, D. A. (2002). Do firms hedge in response to tax incentives? The Journal of Finance, 57(2), 815-839. https://doi.org/10.1111/1540-6261.00443

Haushalter, G. D. (2000). Financing policy, basis risk, and corporate hedging: evidence from oil and gas producers. The Journal of Finance, 55(1), 107-152. https://doi.org/10.2307/222552

International Monetary Fund. (2018). Regional economic outlook. Western Hemisphere: an uneven recovery. Retrieved from https://www.imf.org/en/Publications/WEO/Issues/2018/09/24/world-economic-outlookoctober-2018

Jensen, M. C., \& Meckling, W. H. (1976). Theory of the firm: managerial behavior, agency costs and ownership structure. Journal of Financial Economics, 3(4), 305-360. https://doi.org/10.1016/0304-405X(76)90026-X

Jensen, M. C., \& Warner, J. B. (1988). The distribution of power among corporate managers, shareholders, and directors. Journal of Financial Economics, 20, 3-24. 
https://doi.org/10.1016/0304-405X(88)90038-4

Jin, Y., \& Jorion, P. (2006). Firm value and hedging: evidence from U.S. oil and gas producers. Journal of Finance, 61(2), 893-919. https://doi.org/10.1111/j.15406261.2006.00858.x

Judge, A. (2006). Why and how UK firms hedge. European Financial Management, 12(3), 407-441. https://doi.org/10.1111/j.1354-7798.2006.00326.x

Kim, E. H. (1978). A mean-variance theory of optimal capital structure and corporate debt capacity. The Journal of Finance, 33(1), 45-63. https://doi.org/10.2307/2326349

Kraus, A., \& Litzenberger, R. H. (1973). A state-preference model of optimal financial leverage. The Journal of Finance, 28(4), 911-922. https://doi.org/https://www.jstor.org/stable/2978343

La Porta, R., Lopez-de-Silanes, F., Shleifer, A., \& Vishny, R. (2000). Investor protection and corporate governance. Journal of Financial Economics, 58(1-2), 3-27. https://doi.org/10.1016/S0304-405X(00)00065-9

La Porta, R., Lopez-de-Silanes, F., Shleifer, A., \& Vishny, R. W. (1998). Law and finance. Journal of Political Economy, 106(6), 1113-1155. https://doi.org/10.1086/250042

Lel, U. (2012). Currency hedging and corporate governance: A cross-country analysis. Journal of Corporate Finance, 18(2), 221-237. https://doi.org/10.1016/j.jcorpfin.2011.12.002

Lin, C. M., Phillips, R. D., \& Smith, S. D. (2008). Hedging, financing, and investment decisions: Theory and empirical tests. Journal of Banking and Finance, 32(8), 15661582. https://doi.org/10.1016/j.jbankfin.2007.11.014 
López-Iturriaga, F., García-Meca, E., \& Tejerina-Gaite, F. (2015). Institutional directors and board compensation: Spanish evidence. BRQ Business Research Quarterly, 18(3), 161173. https://doi.org/10.1016/j.brq.2014.07.003

Marshall, A. P., Kemmitt, M., \& Pinto, H. (2013). The determinants of foreign exchange hedging in alternative investment market firms. European Journal of Finance, 19(2), 89111. https://doi.org/10.1080/1351847X.2012.659267

Mello, A. S., \& Parsons, J. E. (2000). Hedging and liquidity. Review of Financial Studies, 13(1), 127-153. https://doi.org/10.1093/rfs/13.1.127

Modigliani, F., \& Miller, M. (1958). The cost of capital, corporation finance and the theory of investment. The American Economic Review, 48(3), 261-297. Retrieved from http://www.jstor.org/stable/1809766

Myers, S. (1984). The capital structure puzzle. The Journal of Finance, 39(3), 575-592. https://doi.org/10.2307/2327916

Nance, D. R., Smith, C. W., \& Smithson, C. W. (1993). On the determinants of corporate hedging. The Journal of Finance, 48(1), 267-284. https://doi.org/10.1111/j.15406261.1993.tb04709.x

OECD, World Bank, \& IMF. (2007). 9th OECD-World Bank-IMF Global Bond Market Forum,. Use of Derivatives for Debt Management and Domestic Debt Market Development - Key Conclusions, 7. Retrieved from http://www.oecd.org/fr/finances/dette-publique/39354012.pdf

Otero González, L., Vivel Búa, M., Fernández López, S., \& Durán Santomil, P. (2010). Foreign debt as a hedging instrument of exchange rate risk: a new perspective. The 
European Journal of Finance, 16(7), 677-710.

https://doi.org/10.1080/1351847X.2010.481455

Rajgopal, S., \& Shevlin, T. (2002). Empirical evidence on the relation between stock option compensation and risk taking. Journal of Accounting and Economics, 33(2), 145-171. https://doi.org/10.1016/S0165-4101(02)00042-3

Schiozer, R. F., \& Saito, R. (2009). The determinants of currency risk management in Latin American nonfinancial firms. Emerging Markets Finance and Trade, 45(1), 49-71. https://doi.org/10.2753/REE1540-496X450104

Smith, C., \& Stulz, R. (1985). The determinants of firm's hedging policies. Journal of Financial and Quantitive Analysis, 20(4), 391-406. https://doi.org/10.2307/2330757

Stulz, R. M. (2004). Should we fear derivatives? The Journal of Economic Perspectives, 18(3), 173-192. https://doi.org/10.2307/3216812

Tanha, H., \& Dempsey, M. (2017). Derivatives usage in emerging markets following the GFC: Evidence from the GCC countries. Emerging Markets Finance and Trade, 53(1), 170-179. https://doi.org/10.1080/1540496X.2016.1157467

Tufano, P. (1996). Who manages risk? An empirical examination of risk management practices in the gold mining industry. The Journal of Finance, 51(4), 1097-1137. https://doi.org/10.1111/j.1540-6261.1996.tb04064.x

Tungsong, S., \& Jiraporn, P. (2016). The effect of family ownership on corporate hedging: the case of Thailand. Applied Economics Letters, 24(12), 882-887. https://doi.org/10.1080/13504851.2016.1237740

World Bank Group. (2018). Databank. Retrieved from Popular Indicators website: 
http://databank.worldbank.org/data/indicator/NE.EXP.GNFS.ZS/1ff4a498/PopularIndicators 
Appendix I. Variables, measurements and expected signs

\begin{tabular}{|c|c|c|}
\hline Label & & Measurement \\
\hline & & Dependent variable \\
\hline$F X R H \_A A$ & $=$ & $\begin{array}{l}\text { Dummy variable that equals } 1 \text { if the firm do FXR hedging; } 0 \\
\text { otherwise }\end{array}$ \\
\hline$F X R H \_d e$ & $=$ & $\begin{array}{l}\text { Dummy variable that equals } 1 \text { if the firm discloses the use of } \\
\text { derivatives to hedge FXR at least one year during the period } \\
(2008-2016) ; 0 \text { otherwise }\end{array}$ \\
\hline FXRH_de & & $\begin{array}{l}\text { Dummy variable that equals } 1 \text { if the firm discloses the use of } \\
\text { derivatives to hedge FXR during at least for } 4 \text { years of the period } \\
(2008-2016) \text {; } 0 \text { otherwise }\end{array}$ \\
\hline DERIV_ASSET & $=$ & $\begin{array}{l}\text { Current derivative assets plus noncurrent derivative assets over } \\
\text { total assets. }\end{array}$ \\
\hline$D E R I V \_L I A B$ & $=$ & $\begin{array}{l}\text { Current derivative liabilities plus noncurrent derivative liabilities } \\
\text { over total debt }\end{array}$ \\
\hline DERIV_CFLOW & $=$ & Absolute value of derivatives unrealized gains or losses in hedging \\
\hline
\end{tabular}

\section{Explanatory variables}

ITP $=$ Income tax payable (accrued tax liability which is due within the normal operating cycle of the company) over total assets.

Leverage $\quad=\quad$ Book value of debt over the market value of company (MVC). For companies with more than one listed equity security, the MVC represents the sum of the individuals listed equities

$I C R=$ Interest cover ratio (EBIT over interest expenses)

Quick

Current assets less inventories over current liabilities

Capex $=$ Natural logarithm of the capital expenditures

Ownership $=$ The highest percentage of the company shares in hands of one shareholder.

Stock_comp $=$ Natural log of the stock option compensations expenses, net of taxes.

\section{Control variables}

Size $\quad=$ Natural logarithm of the total assets at year-end

FXR_index $=$ It is the outcome of adding for each observation: i) the proportion of foreign assets to total assets, and ii) the proportion of foreign sales to total sales. Results are in percentage.

DeltaFX $=$ Foreign exchange currency valuation/devaluation rate of each country-currency respect to the dollar in absolute value.
H1 - $\quad$ Yes

$\mathrm{H} 2 \mathrm{a}+\mathrm{Yes}$

No

No

No

Yes

Yes

Yes

$\mathrm{H} 2 \mathrm{~b} \quad-\quad \mathrm{Yes}$

H3 +/- Yes

$\mathrm{H} 4 \quad+\quad$ Yes

H5 - No

H6 $\quad+\quad$ No

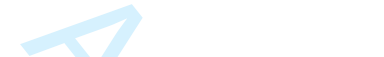

Financial information was taken from Thomson DataStream. Hedging practices was manually collected from the annual reports released in their web sites or, alternatively, in their respective Financial Supervisory Authority web sites. 
Table 1 Distribution of the sample by country for the period 2008-2016

\begin{tabular}{|c|c|c|c|c|c|c|c|c|c|c|c|}
\hline \multirow[b]{2}{*}{ Country } & \multirow[b]{2}{*}{$\begin{array}{c}\text { Total } \\
\text { Firm } \\
\text { s }\end{array}$} & \multirow[b]{2}{*}{$\begin{array}{c}\text { Tota } \\
\text { l } \\
\text { Obs }\end{array}$} & \multirow[b]{2}{*}{$\begin{array}{l}\text { Tota } \\
1 \%\end{array}$} & \multicolumn{4}{|c|}{$\mathbf{N}^{\circ}$ Observations } & \multicolumn{4}{|c|}{$\%$ of observations } \\
\hline & & & & $\underset{0}{\text { FXRH_AA }}=$ & $\underset{1}{\text { FXRH_AA }}=$ & $\underset{1}{\text { FXRH_de }}=$ & FXRH_de_reg= & $\underset{0}{\text { FXRH_AA }}=$ & $\underset{1}{\text { FXRH_AA }}=$ & $\underset{1}{\text { FXRH_de }}=$ & FXRH_de_reg= \\
\hline $\begin{array}{c}\text { Argentin } \\
\mathrm{a}\end{array}$ & 33 & 297 & $10 \%$ & 200 & 97 & 88 & 26 & 16.78 & 5.14 & 5.20 & 2.96 \\
\hline Brazil & 132 & $\begin{array}{c}1,18 \\
8\end{array}$ & $39 \%$ & 426 & 762 & 621 & 299 & 35.74 & 40.40 & 36.68 & 34.09 \\
\hline Chile & 76 & 684 & $22 \%$ & 201 & 483 & 475 & 282 & 16.86 & 25.61 & 28.06 & 32.16 \\
\hline $\begin{array}{c}\text { Colombi } \\
\text { a }\end{array}$ & 16 & 144 & $5 \%$ & 60 & 84 & 66 & 0 & 5.03 & 4.45 & 3.90 & 0.00 \\
\hline Mexico & 51 & 459 & $15 \%$ & 123 & 336 & 327 & 228 & 10.32 & 17.82 & 19.31 & 26.00 \\
\hline Peru & 34 & 306 & $10 \%$ & 182 & 124 & 116 & 42 & 15.27 & 6.57 & 6.85 & 4.79 \\
\hline Total & 342 & $\begin{array}{c}3,07 \\
8\end{array}$ & $\begin{array}{c}100 \\
\%\end{array}$ & 1,192 & 1,886 & 1,693 & 877 & 38.73 & 61.27 & 55.00 & 28.49 \\
\hline
\end{tabular}

FXRH_AA, FXRH_de and FXRH_de_reg equals 1 if the firm hedge, used derivatives to hedge FXR at least one year during the period (2008-2016), and use derivatives regularly to hedge FXR during at least for 4 years of the period (2008-2016); respectively, and 0 otherwise. 
Table 2 Descriptive statistics

\begin{tabular}{|c|c|c|c|c|}
\hline \multirow{2}{*}{ Variables } & \multicolumn{4}{|c|}{$\begin{array}{c}\text { All sample } \\
\mathrm{N}=3,078 \\
\end{array}$} \\
\hline & Mean & Std. Dev. & Min & $\operatorname{Max}$ \\
\hline 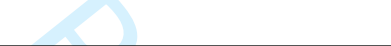 & (1) & (2) & (3) & (4) \\
\hline$F X R H \_A A(1 / 0)$ & 0.613 & 0.487 & 0 & 1 \\
\hline FXRH_de (1/0) & 0.550 & 0.498 & 0 & 1 \\
\hline FXRH_de_reg $(1 / 0)$ & 0.285 & 0.451 & 0 & 1 \\
\hline DERIV_ASSET (\%) & 0.002 & 0.006 & 0 & 0.038 \\
\hline DERIV_LIAB (\%) & 0.010 & 0.034 & 0 & 0.255 \\
\hline DERIV_CFLOW (\%) & 0.022 & 0.097 & 0 & 0.795 \\
\hline ITP (ratio) & 0.011 & 0.017 & 0 & 0.107 \\
\hline Leverage (ratio) & 0.819 & 0.292 & 0.000 & 1.000 \\
\hline ICR (ratio) & 8.660 & 17.681 & 0 & 124.78 \\
\hline Quick (ratio) & 11.247 & 31.959 & 0.103 & 258.79 \\
\hline Capex (Ln) & 9.7607 & 3.301 & 0 & 15.53 \\
\hline Ownership (\%) & 0.458 & 0.255 & 0.015 & 99.999 \\
\hline Stock_comp (Ln) & 0.348 & 1.635 & 0 & 11.21 \\
\hline Size (Ln) & 13.658 & 1.862 & 9.427 & 18.04 \\
\hline$F X R \_$index (\%) & 7.652 & 15.714 & 0 & 80.41 \\
\hline DeltaFX ( $\Delta \%$ in decimals $)$ & 0.094 & 0.092 & 0.000 & 0.469 \\
\hline
\end{tabular}

FXRH_AA, FXRH_de and FXRH_de_reg equals 1 if the firm hedge, used derivatives to hedge FXR at least one year during the period (20082016), and use derivatives regularly to hedge FXR during at least for 4 years of the period (2008-2016); respectively, and 0 otherwise. DERIV_ASSET is a proportion of the total derivatives in assets, calculated as current derivative assets plus noncurrent derivative assets over total assets; DERIV_LIAB is a proportion of the total derivatives in liabilities, calculated as current derivative liabilities plus noncurrent derivative liabilities over total debt; and DERIV_CFLOW is the absolute value of derivatives unrealized gain or losses in hedging positions over EBIT; ITP is the Income Tax Payable over total assets ratio; Leverage is the book value of debt over the market value of company ratio; $I C R$ is the interest cover ratio measured as EBIT over interest expenses; Quick is current assets less inventories over current liabilities ratio; Capex is the natural log of capital expenditures; Ownership is the highest percentage of the company shares in hands of one shareholder; Stock_comp is the natural log of the stock option compensations expenses, net of tax; Size is the natural log of total assets; FXR_index percentage level exposure is the outcome average of adding for each observation: i) the proportion of foreign assets to total assets, and ii) the proportion of foreign sales to total sales; DeltaFX is the foreign exchange currency valuation/devaluation rate of each country-currency respect to the dollar in absolute value. Raw data is in units of US dollars at the year end. 


\section{Table 3 Results of the mean differences (T-test) for FXR coverage}

\begin{tabular}{|c|c|c|c|c|c|c|c|c|c|c|c|c|}
\hline & $\begin{array}{c}\text { FXRH_AA=0 } \\
\mathrm{N}=1,192\end{array}$ & $\begin{array}{c}\text { FXRH_AA=1 } \\
\mathrm{N}=1,886\end{array}$ & $\begin{array}{l}\text { T-test } \\
\text { Diff. } \\
(2)-(1)\end{array}$ & & $\begin{array}{c}\text { FXRH_de }=0 \\
\mathrm{~N}=193\end{array}$ & $\begin{array}{c}\text { FXRH_de }=1 \\
\mathrm{~N}=1,693\end{array}$ & $\begin{array}{l}\text { T-test } \\
\text { Diff. } \\
(5)-(4)\end{array}$ & & $\begin{array}{c}\text { FXRH_de_reg }=0 \\
\mathrm{~N}=816\end{array}$ & $\begin{array}{c}\text { FXRH_de_reg }=1 \\
\mathrm{~N}=877\end{array}$ & $\begin{array}{c}\text { T-test } \\
\text { Diff. } \\
(8)-(7)\end{array}$ & \\
\hline & (1) & (2) & (3) & & (4) & $(5)$ & $(6)$ & & (7) & (8) & (9) & \\
\hline$I T P$ & 0.012 & 0.010 & -0.002 & $* * *$ & 0.009 & 0.01 & 0.001 & & 0.011 & 0.009 & -0.002 & $* * *$ \\
\hline Leverage & 0.747 & 0.865 & 0.118 & $* * *$ & 0.829 & 0.870 & 0.041 & $* *$ & 0.823 & 0.913 & 0.090 & $* * *$ \\
\hline$I C R$ & 8.207 & 8.947 & 0.740 & & 5.795 & 9.306 & 3.511 & $* *$ & 12.249 & 6.568 & -5.681 & $* * *$ \\
\hline Quick & 10.760 & 11.555 & 0.795 & & 5.850 & 12.205 & 6.355 & $* *$ & 12.606 & 11.832 & -0.774 & \\
\hline Capex & 8.283 & 10.693 & 2.410 & $* * *$ & 9.456 & 10.834 & 1.378 & $* * *$ & 10.117 & 11.501 & 1.384 & $* * *$ \\
\hline Ownership & 0.842 & 0.477 & -0.365 & $* *$ & 0.478 & 0.477 & -0.001 & & 0.554 & 0.405 & -0.149 & \\
\hline Stock_comp & 0.185 & 0.452 & 0.267 & $* * *$ & 0.401 & 0.458 & 0.057 & & 0.377 & 0.533 & 0.156 & $*$ \\
\hline Size & 12.545 & 14.362 & 1.817 & $* * *$ & 13.730 & 14.434 & 0.704 & $* * *$ & 13.849 & 14.979 & 1.130 & $* * *$ \\
\hline$F X R$ index & 3.226 & 10.449 & 7.223 & $* * *$ & 3.315 & 11.263 & 7.948 & $* * *$ & 6.645 & 15.559 & 8.914 & $* * *$ \\
\hline DeltāFX & 0.099 & 0.092 & -0.007 & $* *$ & 0.107 & 0.090 & -0.017 & $* * *$ & 0.093 & 0.087 & -0.006 & \\
\hline
\end{tabular}

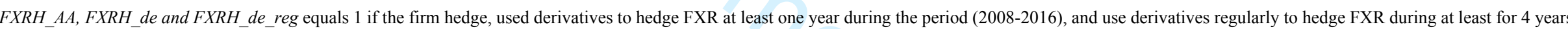

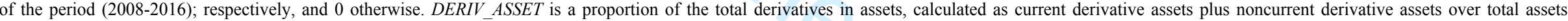

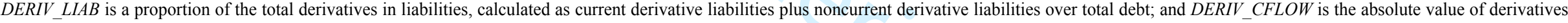

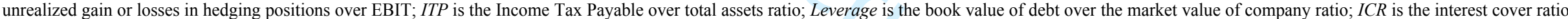

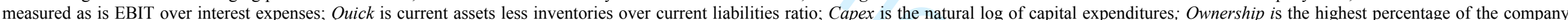

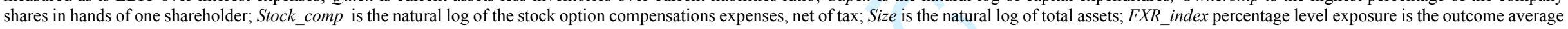

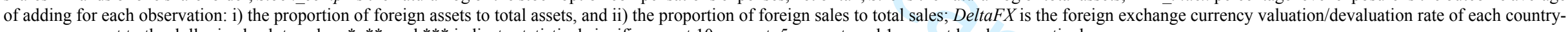
currency respect to the dollar in absolute value. $*^{* *}$, and $* * *$ indicate statistical significance at 10 percent, 5 percent, and 1 percent levels, respectively. 


\section{Table 4 Results of the Logit regressions}

\begin{tabular}{|c|c|c|c|c|c|c|c|c|c|c|c|c|c|c|c|c|c|c|c|}
\hline \multirow[b]{3}{*}{ Variables } & $H=1$ & $=\alpha+\beta_{1} I$ & $T P_{i t}$ & Leverage & $e_{i t}$ & $C R_{i t}+\beta_{4}$ & Quic & $+\beta_{5}$ Capex $_{i}$ & $c_{i t}$ & $w_{n e r}+\beta$ & ${ }_{7} \mathrm{Stc}$ & $\varepsilon_{-} \operatorname{Comp}_{i t}+$ & $-\beta_{8}$ & ${ }_{i t}+\beta_{9} F X R$ & ind & ${ }_{i t}+\beta_{10}$ Delt & $\operatorname{taF}$ & $+\varepsilon_{i t}$ & \\
\hline & \multirow[b]{2}{*}{$\begin{array}{l}\text { Exp. } \\
\text { Sign }\end{array}$} & \multicolumn{5}{|c|}{ FXRH_AA (Model 1) } & & \multicolumn{6}{|c|}{ FXRH_de (Model 2) } & \multicolumn{5}{|c|}{ FXRH_de_reg (Model 3) } & \\
\hline & & Extended & & $\begin{array}{c}C S \\
\text { removed }\end{array}$ & & $\begin{array}{c}C G \\
\text { removed }\end{array}$ & & Extended & & $\begin{array}{c}C S \\
\text { removed }\end{array}$ & & $\begin{array}{c}C G \\
\text { removed }\end{array}$ & & Extended & & $\begin{array}{c}C S \\
\text { removed }\end{array}$ & & $\begin{array}{c}C G \\
\text { removed }\end{array}$ & \\
\hline \multirow[t]{2}{*}{ ITP } & - & -7.862 & $* * *$ & & & -7.604 & $* * *$ & -5.617 & $* *$ & & & -5.380 & $* *$ & -9.419 & $* * *$ & & & -8.999 & $* *$ \\
\hline & & $(-3.11)$ & & & & $(-3.02)$ & & $(-2.22)$ & & & & $(-2.13)$ & & $(-2.77)$ & & & & $(-2.65)$ & \\
\hline \multirow[t]{2}{*}{ Leverage } & + & 0.249 & & & & 0.256 & & 0.292 & $*$ & & & 0.296 & $*$ & 0.784 & $* * *$ & & & 0.809 & $* *$ \\
\hline & & $(1.582)$ & & & & $(1.625)$ & & $(1.835)$ & & & & $(1.869)$ & & $(3.512)$ & & & & $(3.648)$ & \\
\hline \multirow[t]{2}{*}{$I C R$} & - & 0.007 & $* *$ & & & 0.007 & $* * *$ & 0.009 & $* * *$ & & & 0.009 & $* * *$ & -0.009 & $* * *$ & & & -0.009 & $* *$ \\
\hline & & $(2.555)$ & & & & $(2.625)$ & & $(3.376)$ & & & & $(3.426)$ & & $(-2.59)$ & & & & $(-2.61)$ & \\
\hline \multirow[t]{2}{*}{ Quick } & $+/-$ & 0.001 & & & & 0.001 & & 0.003 & $*$ & & & 0.002 & $*$ & 0.004 & $* * *$ & & & 0.004 & $* *$ \\
\hline & & $(0.908)$ & & & & $(0.692)$ & & (1.912) & & & & $(1.701)$ & & $(2.833)$ & & & & $(2.552)$ & \\
\hline \multirow[t]{2}{*}{ Capex } & + & 0.029 & $*$ & & & 0.027 & & 0.047 & $* * *$ & & & 0.044 & $* * *$ & 0.051 & $* *$ & & & 0.048 & $* *$ \\
\hline & & (1.665) & & & & (1.61) & & $(2.744)$ & & & & $(2.63)$ & & $(2.358)$ & & & & $(2.27)$ & \\
\hline \multirow[t]{2}{*}{ Ownership } & - & -0.038 & $* * *$ & -0.036 & $* * *$ & & & -0.037 & $* * *$ & 0.003 & $* * *$ & & & -0.259 & & -0.011 & $* *$ & & \\
\hline & & $(-3.06)$ & & $(-2.97)$ & & & & $(-2.90)$ & & $(0.104)$ & & & & $(-1.29)$ & & $(-0.42)$ & & & \\
\hline \multirow[t]{2}{*}{ Stock_comp } & + & 0.002 & & 0.008 & $* * *$ & & & -0.005 & & 0.574 & & & & -0.014 & & 0.604 & & & \\
\hline & & $(0.058)$ & & $(0.259)$ & & & & $(-0.18)$ & & $(20.21)$ & & & & $(-0.51)$ & & $(18.70)$ & & & \\
\hline \multirow[t]{2}{*}{ Size } & + & 0.593 & $* * *$ & 0.631 & $* * *$ & 0.592 & $* * *$ & 0.520 & $* * *$ & 0.026 & $* * *$ & 0.518 & $* * *$ & 0.525 & $* * *$ & 0.024 & $* * *$ & 0.525 & $* * *$ \\
\hline & & (16.27) & & $(21.20)$ & & (16.44) & & $(14.86)$ & & $(6.913)$ & & (14.98) & & (12.94) & & $(8.166)$ & & (13.10) & \\
\hline \multirow[t]{2}{*}{$F X R \_$index } & + & 0.020 & $* * *$ & 0.020 & $* * *$ & 0.018 & $* * *$ & 0.025 & $* * *$ & -1.376 & $* * *$ & 0.024 & $* * *$ & 0.023 & $* * *$ & -1.250 & $* * *$ & 0.022 & $* * *$ \\
\hline & & (4.979) & & $(5.187)$ & & (4.690) & & $(6.660)$ & & $(-3.76)$ & & $(6.428)$ & & (7.608) & & $(-2.97)$ & & $(7.465)$ & \\
\hline \multirow[t]{2}{*}{ DeltaFX } & $+/-$ & -1.125 & $* * *$ & -1.268 & $* * *$ & -1.10 & $* *$ & -1.619 & $* * *$ & -1.761 & $* * *$ & -1.603 & $* * *$ & -2.163 & $* * *$ & -20.16 & $* * *$ & -2.18 & $* * *$ \\
\hline & & $(-2.36)$ & & $(-2.73)$ & & $(-2.34)$ & & $(-3.43)$ & & $(-3.82)$ & & $(-3.44)$ & & $(-3.83)$ & & $(-3.63)$ & & $(-3.94)$ & \\
\hline$N^{\circ}$ Observations & & 3,078 & & 3,078 & & 3,078 & & 3,078 & & 3,078 & & 3,078 & & 3,078 & & 3,078 & & 3,078 & \\
\hline Log-likelihood & & -1629.48 & & -1641.43 & & -1636.42 & & -1698.47 & & -1716.72 & & -1704.91 & & -1424.78 & & -1445.69 & & -1431.06 & \\
\hline Chi2 - CS rem & & 826.32 & $* * *$ & & & & & 802.70 & $* * *$ & & & & & 787.1 & $* * *$ & & & & \\
\hline Chi2 - CG rem & & 836.33 & $* * *$ & & & & & 826.32 & $* * *$ & & & & & 816.35 & $* * *$ & & & & \\
\hline Predictive Power & & $74.43 \%$ & & $73.85 \%$ & & $74.43 \%$ & & $71.12 \%$ & & $70.37 \%$ & & $70.99 \%$ & & $76.90 \%$ & & $76.25 \%$ & & $76.48 \%$ & \\
\hline Pseudo R2 & & 0.207 & & 0.201 & & 0.203 & & 0.198 & & 0.189 & & 0.195 & & 0.225 & & 0.214 & & 0.222 & \\
\hline
\end{tabular}

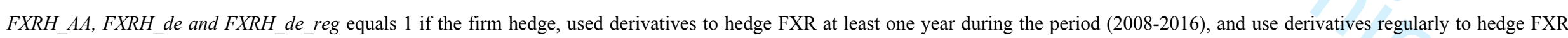

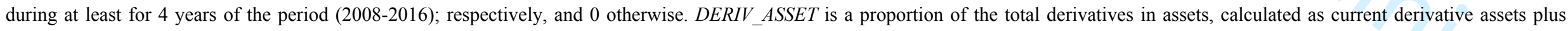

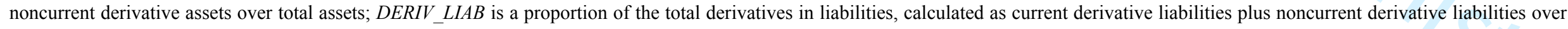

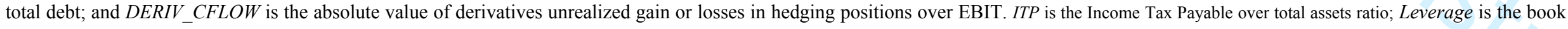


value of debt over the market value of company ratio; ICR is the interest cover ratio measured as EBIT over interest expenses; Quick is current assets less inventories over current liabilities ratio; Capex is the natural log of capital expenditures; Ownership is the highest percentage of the company shares in hands of one shareholder; Stock_comp is the natural log of the stock option compensations expenses, net of tax; Size is the natural log of total assets; FXR index percentage level exposure is the outcome average of adding for each observation: i) the proportion of foreign assets to total assets, and ii) the proportion of foreign sales to total sales; DeltaFX is the foreign exchange currency valuation/devaluation rate of each country-currency respect to the dollar in absolute value. $*, * *$, and $* * *$ indicate statistical significance at 10 percent, 5 percent, and 1 percent levels, respectively. 


\section{Table 5 Results of the Tobit regressions}

\begin{tabular}{|c|c|c|c|c|c|c|c|c|c|c|c|c|c|c|c|c|c|c|}
\hline \multirow[b]{2}{*}{ Variables } & \multirow{2}{*}{ Exp. Sign } & \multicolumn{4}{|c|}{ DERIV_ASSET (Model 4) } & & \multicolumn{6}{|c|}{ DERIV_LIAB (Model 5) } & \multicolumn{5}{|c|}{ DERIV_CFLOW (Model 6) } & \\
\hline & & Extended & $\begin{array}{c}C S \\
\text { removed }\end{array}$ & & $\underset{\text { removed }}{C G}$ & & Extended & & $\underset{\text { removed }}{C S}$ & & $\underset{\text { removed }}{C G}$ & & Extended & & $\underset{\text { removed }}{C S}$ & & $\underset{\text { removed }}{C G}$ & \\
\hline \multirow[t]{2}{*}{ ITP } & - & $-0.074 * * *$ & & & -0.071 & $* * *$ & -0.163 & & & & -0.158 & & -1.227 & $* * *$ & & & -1.223 & $* * *$ \\
\hline & & $(-2.75)$ & & & $(-2.64)$ & & $(-1.34)$ & & & & $(-1.306)$ & & $(-2.62)$ & & & & $(-2.61)$ & \\
\hline \multirow[t]{2}{*}{ Leverage } & + & 0.003 & & & 0.003 & $*$ & 0.080 & & & & 0.008 & & 0.036 & & & & 0.037 & \\
\hline & & $(1.550)$ & & & $(1.880)$ & & $(1.03)$ & & & & $(1.046)$ & & $(1.260)$ & & & & $(1.295)$ & \\
\hline \multirow[t]{2}{*}{ ICR } & - & -0.000 & & & -0.000 & & -0.000 & & & & -0.000 & & -0.000 & & & & -0.000 & \\
\hline & & $(-0.510)$ & & & $(-0.617)$ & & $(-0.473)$ & & & & $(-0.428)$ & & $(0.518)$ & & & & $(0.587)$ & \\
\hline \multirow[t]{2}{*}{ Quick } & $+/-$ & 0.000 & & & 0.000 & & 0.000 & $* * *$ & & & 0.000 & $* * *$ & 0.000 & & & & 0.000 & \\
\hline & & $(0.103)$ & & & $(0.006)$ & & $(3.327)$ & & & & $(3.311)$ & & $(0.053)$ & & & & $(0.143)$ & \\
\hline \multirow[t]{2}{*}{ Capex } & + & 0.000 & & & 0.000 & & 0.002 & $* * *$ & & & 0.002 & $* * *$ & 0.003 & & & & 0.003 & \\
\hline & & (1.404) & & & $(1.562)$ & & (2.683) & & & & $(2.695)$ & & $(0.955)$ & & & & $(0.978)$ & \\
\hline \multirow[t]{2}{*}{ Ownership } & - & $-0.005 * * *$ & -0.005 & $* * *$ & & & -0.001 & & -0.001 & & & & -0.001 & & -0.001 & & & \\
\hline & & $(-2.890)$ & $(-3.148)$ & & & & $(-1.516)$ & & $(-1.314)$ & & & & $(-0.715)$ & & $(-0.645)$ & & & \\
\hline \multirow[t]{2}{*}{ Stock_comp } & - & 0.000 & 0.000 & & & & 0.001 & & 0.001 & & & & 0.006 & $*$ & 0.006 & $*$ & & \\
\hline & & $(0.025)$ & $(0.034)$ & & & & $(1.301)$ & & (1.537) & & & & (1.786) & & $(1.851)$ & & & \\
\hline \multirow[t]{2}{*}{ Size } & + & $0.004 * * *$ & 0.005 & $* * *$ & 0.004 & $* * *$ & 0.015 & $* * *$ & 0.01 & $* * *$ & 0.016 & $* * *$ & 0.045 & $* * *$ & 0.049 & $* * *$ & 0.045 & $* * *$ \\
\hline & & (12.83) & (17.35) & & (13.09) & & (10.13) & & $(15.21)$ & & (10.34) & & (7.679) & & (10.794) & & (7.918) & \\
\hline \multirow[t]{2}{*}{$F X R_{-}$index } & + & $0.000 * * *$ & 0.000 & $* * *$ & 0.000 & $* * *$ & 0.000 & $* * *$ & 0.000 & $* * *$ & 0.000 & $* * *$ & 0.001 & $* *$ & 0.001 & $* *$ & 0.001 & $* *$ \\
\hline & & $(2.825)$ & (3.153) & & $(2.836)$ & & $(4.277)$ & & $(4.536)$ & & (4.192) & & $(2.180)$ & & $(2.380)$ & & (2.097) & \\
\hline \multirow[t]{2}{*}{ DeltaFX } & $+/-$ & 0.001 & 0.001 & & 0.001 & & -0.056 & $* * *$ & -0.058 & $* * *$ & -0.052 & $* * *$ & 0.131 & * & 0.126 & $*$ & 0.149 & $* *$ \\
\hline & & $(0.386)$ & $(0.371)$ & & $(-0.334)$ & & $(-2.629)$ & & $(-2.779)$ & & $(-2.46)$ & & $(1.756)$ & & $(1.721)$ & & (2.016) & \\
\hline$N^{\circ}$ Obs. & & 3,078 & 3,078 & & 3,078 & & 3,078 & & 3,078 & & 3,078 & & 3,078 & & 3,078 & & 3,078 & \\
\hline Likelihood & & 1335.902 & 1328.932 & & 1329.368 & & 196.605 & & 184.663 & & 193.920 & & -901.396 & & -906.071 & & -902.972 & \\
\hline$C h i^{2}-C S$ & & $605.270 * * *$ & & & & & 457.390 & $* * *$ & & & & & 218.520 & $* * *$ & & & & \\
\hline$C h i^{2}-C G$ & & $606.150 * * *$ & & & & & 474.960 & $* * *$ & & & & & 224.590 & *** & & & & \\
\hline Pseudo R2 & & -0.302 & -0.295 & & -0.295 & & 4.99 & & 4.761 & & 4.944 & & 0.124 & & 0.107 & & 0.110 & \\
\hline AIC & & -2575.420 & -2601.640 & & -2578.420 & & -296.826 & & -313.102 & & -307.519 & & 1899.180 & & 1868.370 & & 1886.260 & \\
\hline
\end{tabular}

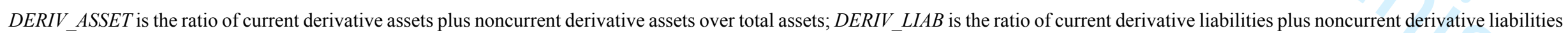

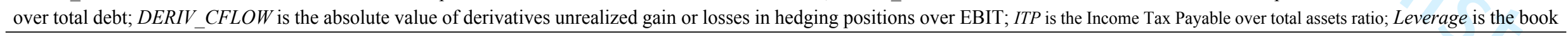


value of debt over the market value of company ratio; ICR is the interest cover ratio measured as EBIT over interest expenses; Quick is current assets less inventories over current liabilities ratio; Capex is the natural log of capital expenditures; Ownership is the highest percentage of the company shares in hands of one shareholder; Stock_comp is the natural log of the stock option compensations expenses, net of tax; Size is the natural log of total assets; FXR_index percentage level exposure is the outcome average of adding for each observation: i) the proportion of foreign assets to total assets, and ii) the proportion of foreign sales to total sales; DeltaFX is the foreign exchange currency valuation/devaluation rate of each country-currency respect to the dollar in absolute value. AIC - Akaike's Information Criterion provides a measure of model quality obtained by simulating the situation where the model is tested on a different data set. After computing several different models, AIC is used to compare them. According to Akaike's theory, the most accurate model has the smallest AIC. The t-statistic values are in parentheses. *, **, and *** indicate statistical significance at 10 percent, 5 percent, and 1 percent levels, respectively.

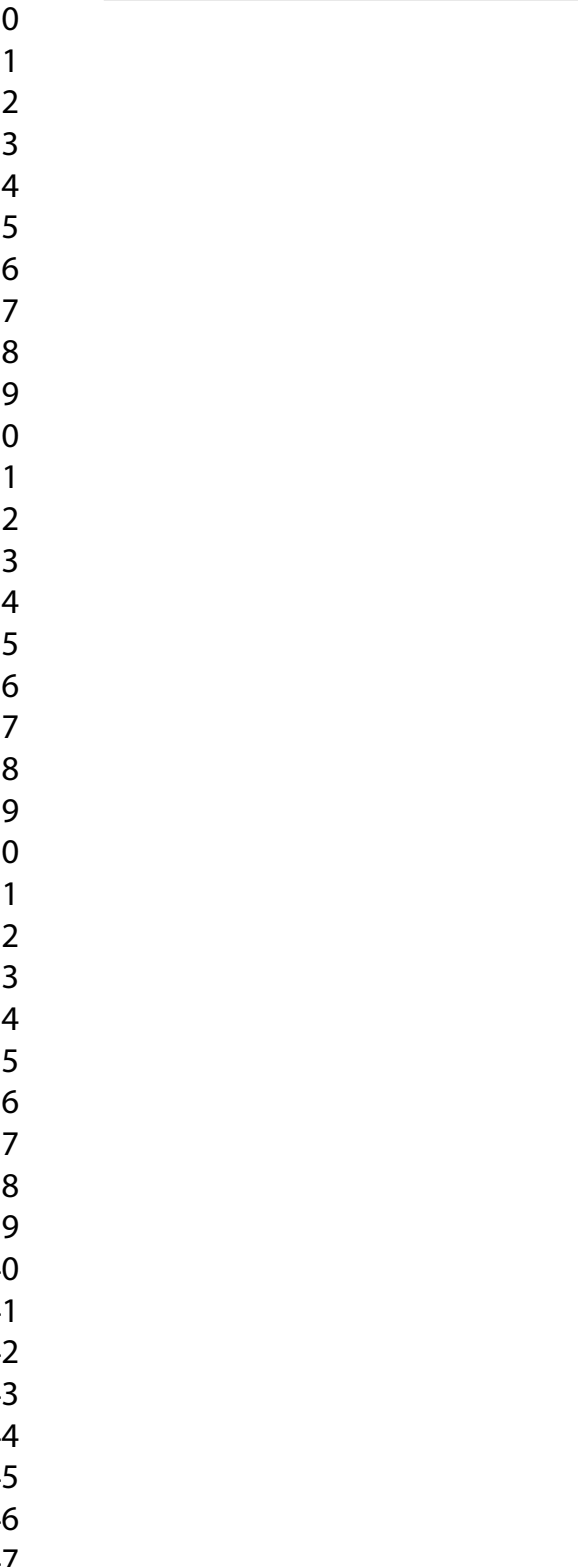


2

3

4

5

6

7

8

9

10

11

12

13

14

15

16

17

18

19

20

21

22

23

24

25

26

27

28

29

30

31

32

33

34

35

36

37

38

39

40

41

42

43

44

45

46

47

48

49

50

51

52

53

54

55

56

57

58

59

60 